\title{
Oat grain yield under nitrogen uses in an eucalyptus intercropping system in Subtropical Brazil ${ }^{1}$
}

\author{
Rendimento da aveia sob aplicações de nitrogênio em agrofloresta com eucalipto no \\ subtrópico brasileiro
}

\author{
Leonardo Deiss ${ }^{2 *}$, Anibal de Moraes ${ }^{3}$, Adelino Pelissari ${ }^{3}$, Vanderley Porfírio da Silva ${ }^{4}$ and Veruschka Rocha \\ Medeiros Andreolla ${ }^{2}$
}

\begin{abstract}
Agronomic practices adequacy plays a key role in the integrated crop-livestock systems development. The objective of this study was to determine how the phytomass accumulation, yield compounds and oat (Avena sativa L. cv. IPR 126) yield were influenced by nitrogen levels (12 and $\left.80 \mathrm{~kg} \mathrm{~N} \mathrm{ha}^{-1}\right)$ at five equidistant positions between two adjacent eucalyptus (Eucalyptus dunnii Maiden) double line tracks [20 m (4 m x $3 \mathrm{~m})$ ] in intercropping system (IS) and traditional no-till agriculture (without trees) in subtropical Brazil. The experiment was conducted in a split-block in a randomized block design with four replicates. At the end of the oat cycle, there was compensation for the lower spikelets per panicle number by the greater grain per spikelet number, and for higher harvest indexes where oat accumulated less phytomass in environments with high interspecific interaction. The nitrogen levels increase the oat yield differently at positions relative to the trees in the IS. Therefore different nitrogen levels should be used at those distances to increase nitrogen use efficiency inside IS in subtropical Brazil.
\end{abstract}

Key words: Fertilization. Interspecific competition. Lodging. Small cereal.

RESUMO - A adequação das práticas agronômicas é ferramenta chave para o desenvolvimento dos sistemas integrados de produção agropecuária (SIPA). O objetivo deste estudo foi determinar como o acúmulo de fitomassa, componentes de rendimento e rendimento da aveia (Avena sativa L. cv. IPR 126) são influenciados por doses de nitrogênio (12 e $80 \mathrm{~kg} \mathrm{~N}^{-1}$ ) em cinco posições equidistantes entre renques com linhas duplas [20 m (4 m x $3 \mathrm{~m})]$ de eucaliptos (Eucalyptus dunnii Maiden) em SIPA e em agricultura tradicional (sem árvores) em sistemas sem revolvimento do solo no subtrópico brasileiro. O experimento foi conduzido em faixas, em delineamento de blocos ao acaso com quatro repetições. No final do ciclo da aveia, verificou-se compensação do menor número de espiguetas por panícula pelo maior número de grãos por espigueta, assim como maiores índices de colheita onde a aveia acumulou menos fitomassa, em ambientes com alta interação interespecífica. O nitrogênio aumentou o rendimento da aveia diferentemente em posições relativas às árvores em SIPA. Portanto, diferentes doses de nitrogênio podem ser usadas nestas posições para aumentar a eficiência no uso no nitrogênio em SIPA com eucaliptos no subtrópico do Brasil.

Palavras-chave: Adubação. Competição interespecífica. Acamamento. Pequenos cereais.

\footnotetext{
*Autor para correspondência

DOI: $10.5935 / 1806-6690.20160056$

'Recebido para publicação em 29/11/2014; aprovado em 14/09/2015

Extraído da Dissertação do primeiro autor, este trabalho foi auxiliado por bolsa de produtividade em pesquisa do CNPq e pelo Projeto de Redes Nacionais de Pesquisa em Agrobiodiversidade e Sustentabilidade Agropecuária/REPENSA, Processo 562688/2010-2, trabalho resultante do termo de cooperação técnica SAIC/AJU no 21500.10/0008-2 firmado entre IAPAR e Embrapa Florestas

${ }^{2}$ Programa de Pós Graduação em Agronomia/Produção Vegetal, Universidade Federal do Paraná/UFPR, Rua dos Funcionários, 1.540, Curitiba- PR, Brasil, 80.035-050, leonardodeiss@gmail.com, vandreolla@yahoo.com.br

${ }^{3}$ Departamento de Fitotecnia e Fitossanitarismo, Universidade Federal do Paraná/UFPR, Rua, dos Funcionários, 1.540, Curitiba-PR, Brasil, 80.035-050, anibalm@ufpr.br, linopeli@ hotmail.com

${ }^{4}$ Embrapa Florestas, Colombo-PR, Brasil, vanderley.porfirio@embrapa.br
} 


\section{INTRODUCTION}

Trees impact the ecological balance of intercropping system (IS), which could be beneficial or harmful. Because tree crops have more competitive ability, agronomic and silvicultural practices should favor the growth and development of an annual crop under interspecific interference. The competition for water and nutrients affects the annual crop component more than the trees, and the intensity increases with trees density and age increase (GILL; SINGH; KAUR, 2009). For example, pruning the trees branches, reduce tree density by altering row spacing (PRASAD et al., 2010) and thinning, are practices that could improve the yield potential of the system. Pruning could promote more sun flecks over intercropped culture; with a tendency to alleviate the qualitative imbalance of transmitted photosynthetic active radiation (KOHLI; SAINI, 2003).

Oat breeding programs in Brazil still do not have a main focus of creating varieties for arborized integrated systems. Semchenko and Zobel (2005) investigated four oat varieties originating from four different years (1930, 1952, 1980 and 1999) to find the effects of light and nutrients on the phenotypic plasticity of oats. The authors observed that oats did not have ontogenetic plasticity in their allocation of photoassimilates to leaves in response to light or to panicles and stems in response to light and nutrients (SEMCHENKO; ZOBEL, 2005). Alterations in wheat yields inside a 4 to 6 year old poplar (Populus deltoides Bartr.) in an agroforestry system are attributed to genetic variation in response to shade and nutrient as well as moisture stresses from the trees (GILL; SINGH; KAUR, 2009).

Because variety principally determines grain quality, agronomic practices should focus on yield and lodging risks (BROWNE; WHITE; BURKE, 2003). Adjusting the nitrogen levels in oat cultivation is important because increases yield and reduces lodging (BROWNE; WHITE; BURKE, 2006). Oat yields can increase as result of nitrogen by increasing the panicle and grain per panicle numbers (BROWNE; WHITE; BURKE, 2006) and when the oats are taller, lodging will negatively affect yield and prolong harvest (WHITE; MCGAREL; RUDDLE, 2003). Poorly filled grains have an increase in moisture content and decrease in specific weight and discoloration from pathogenic activity (WHITE; MCGAREL; RUDDLE, 2003).

The hypothesis of this work is that oat grain yield is increased by nitrogen in positions between eucalyptus tracks in IS, so nitrogen does improve oat yield in IS in subtropical Brazil.
The objective with this study was to determine how the phytomass accumulation, yield compounds and oat (Avena sativa L. cv. IPR 126) yield are influenced by nitrogen levels in positions between adjacent tracks of eucalyptus in IS and in a traditional no-till agriculture (AGR), without trees in subtropical Brazil.

\section{MATERIALS AND METHODS}

This study was conducted at the Experimental Station Model Farm of the Agronomic Institute of Paraná $\left(25^{\circ} 06^{\prime} 19^{\prime \prime}\right.$ S $50^{\circ} 02^{\prime} 38^{\prime \prime} \mathrm{W}, 1020 \mathrm{~m}$ above mean sea level) located in Ponta Grossa, Paraná, Brazil. According to the Köppen classification system, the climate is temperate, with no definite dry season, and the average total annual rainfall, temperature, evapotranspiration and relative humidity are between 1600 to $1800 \mathrm{~mm}, 17$ to $18{ }^{\circ} \mathrm{C}, 900$ to $1000 \mathrm{~mm}$ and 70 to $75 \%$, respectively (CAVIGLIONE et al., 2000).

According to Santos et al. (2006), the soil classification of the study area is a typical dystrophic red-yellow Latosol, with a moderate, mild medium texture and a wavy soft relief phase (4-8\% slope). Soil samples were collected at $0-0.20 \mathrm{~m}$ depth at a positions level as described below and was mixed to form a composite sample for the whole experimental area. Soil analysis revealed the following characteristics (means \pm standard deviation, $\mathrm{n}=6): \mathrm{pH}\left(\mathrm{CaCl}_{2}\right) 4.9 \pm 0.20, \mathrm{pH}$ (SMP) $6.2 \pm 0.15, \mathrm{Al}^{+3} 0.13 \pm 0.13 \mathrm{cmol}_{\mathrm{c}} \mathrm{dm}^{-3}, \mathrm{H}^{+}+\mathrm{Al}^{+3}$ $4.43 \pm 0.55 \mathrm{cmol}_{\mathrm{c}} \mathrm{dm}^{-3}, \mathrm{Ca}^{+2} 3.07 \pm 0.79 \mathrm{cmol}_{\mathrm{c}} \mathrm{dm}^{-3}$, $\mathrm{Mg}^{+2} 2.47 \pm 0.37 \mathrm{cmol}_{\mathrm{c}} \mathrm{dm}^{-3}, \mathrm{~K}^{+} 0.12 \pm 0.03 \mathrm{cmol}_{\mathrm{c}} \mathrm{dm}^{-3}$, $\mathrm{P} 6.65 \pm 2.17 \mathrm{mg} \mathrm{dm}^{-3}, \mathrm{C} 26.4 \pm 1.3 \mathrm{~g} \mathrm{dm}^{-3}$ and clay 447 $\pm 16 \mathrm{~g} \mathrm{~kg}^{-1}$.

The IS trees were eucalyptus, which were planted in 2007, in a double line tracks design. AGR was used as a control to compare the predominant form of agriculture in the region and was located next to the arborized system (less than $200 \mathrm{~m}$ ). Both systems were previously native grassland and had similar cultural histories.

The tree tracks were positioned at a guideline level, in which the track located in the center of the slope, was made in level, and other adjacent tracks were placed in parallel up and down the slope (PORFÍRIODA-SILVA et al., 2009). The spacing between two adjacent tree tracks (intercropped track) along the guideline level direction was $20 \mathrm{~m}$, the distance between two adjacent rows in a track was $4 \mathrm{~m}$, and the distance between two trees in a row was $3 \mathrm{~m}$.

The average tree height and diameter at breast height on December 2011 were $17.41 \mathrm{~m}$ and $21.22 \mathrm{~cm}$, respectively. The smallest eucalyptus trees were thinned 
out $(20 \%)$, and the remaining trees had their branches pruned to half of the tree height. Intercropped annual crops were planted one meter from the tree stems because of a physical limitation related to agricultural implement measurements, making oat tracks $18 \mathrm{~m}$ long.

Six days prior to sowing the oats, glyphosate $(0.9 \mathrm{~kg}$ ae ha-1) was applied to eliminate the remaining weeds from corn (Zea mays L.), which was the preceding crop. The oats were sown under a no-till system at $40 \mathrm{~kg}$ seeds ha-1 and were fertilized at $300 \mathrm{~kg} \mathrm{ha}^{-1}$ of 04-13.1-8.3 (N-P-K) on June 16th, 2011. Seedling emergence occurred ten days after sowing, and this date was used as a reference. During the oat cycle, metsulfuron-methyl (2.4 $\mathrm{g}$ ai ha-1) was applied to control weeds before the tillering stage and pyraclostrobin + epoxiconazole $\left(183 \mathrm{~g}\right.$ ai ha $\left.{ }^{-1}\right)$ was applied to control diseases at the booting stage. At the tillering stage, which started approximately 28 days after emergence (DAE), nitrogen in urea form $(46 \% \mathrm{~N})$ was uniformly hand-applied $\left(68.0 \mathrm{~kg} \mathrm{~N} \mathrm{ha}^{-1}\right)$ or not-applied $\left(0.0 \mathrm{~kg} \mathrm{~N} \mathrm{ha}^{-1}\right)$.

Five positions between the eucalyptus tracks and one outside the intercropping system were evaluated, which were denoted as A, B, C, D and E for IS and F for AGR. The positions within the integrated system with trees (from A to E) were the distances between the tree tracks. The letter A represented the smallest elevation of the slope and the letter $\mathrm{E}$ was the highest elevation of the slope. This designation is always valid because the system was implemented with a guideline level. Therefore, the distances, which are denoted here as positions, represented the oats growing at A: $2.8 \mathrm{~m}, \mathrm{~B}$ : $6.4 \mathrm{~m}, \mathrm{C}: 10.0 \mathrm{~m}, \mathrm{D}: 13.6 \mathrm{~m}$ and $\mathrm{E}: 17.2 \mathrm{~m}$ away from the track positioned at the lowest elevation of the slope between two adjacent eucalyptus double line tracks.

When plants were physiologically mature, evaluations were made to determine their accumulated phytomass (biological yield), yield compounds, yield and harvest index. The oat yield were estimated only for the area of oat track, not including the eucalyptus tracks area, which determined the real oat yield ha ${ }^{-1}$ from the IS. The grain yield was corrected to $13 \%$ moisture.

Each experimental unit consisted of 14 rows that were $5 \mathrm{~m}$ long with $18 \mathrm{~cm}$ between the rows. A $0.4 \mathrm{~m}$ border was left on each experimental unit side. At the end of the oat cycle, the plants were collected from a central position of the experimental unit by placing a $1.8 \mathrm{~m}$ long by $10 \mathrm{~cm}$ wide rectangular cast iron (positioned perpendicular to the trees tracks) that comprised 10 crop rows with $10 \mathrm{~cm}$ length. The plants were uprooted to enable tiller identification, and then the roots were cut for dry matter determination. All collected plants were separated into main stem and tillers, and each plant was broken into leaves, stems, senescent material and panicles, and dried at $65^{\circ} \mathrm{C}$ and weighed after reaching a constant weight.

The panicles were counted, and twelve main stem panicles and five tillers panicles were chosen by random selection for determining the spikelet number, spikelet aborted number, and the number and weights of primary and secondary grains with husks by hand. The weights of the primary grains were determined separately from spikelets with one or two grains. For the other panicles, the grains were threshed with a motorcycle tire chamber and separated from other materials (rachis, branches, and glumes) with a pressurized air blower. The grains were re-dried at $65{ }^{\circ} \mathrm{C}$ and weighed after reaching a constant weight. At the harvest, the total above-ground biological yield and grain with husk yield were used to determine the harvest index (without grain moisture). The proportion of harvested grain husks was accessed by a sub-sample of 10 primary and secondary grains from each experimental unit. The linear relationship of the grain weights with and without husks demonstrates an increase of $1.27 \mathrm{~g} \mathrm{~g}^{-1}$ (intercept $=0.0025$ ) for primary grains $\left(\mathrm{R}^{2}=0.96\right)$ and $1.19 \mathrm{~g} \mathrm{~g}^{-1}$ (intercept $\left.=0.0016\right)$ for secondary grains $\left(\mathrm{R}^{2}=0.95\right)$ compared to the same without husks. Thus was assumed the values of grains with husks.

The statistical analyses were performed using a framework split-block design, in the General Linear Models procedure of Statistica 8.0 for Windows (StatSoft, Inc., Tulsa, OK, USA), with the following factors: positions (five positions between two eucalyptus tracks and AGR) and levels of nitrogen (supply or nonsupply of additional nitrogen at tillering stage). Other analyses were performed as described, excluding the treatment control (AGR), using five positions between two eucalyptus tracks and two nitrogen levels to test the effects only within the integrated system (DEISS et al., 2014a, b). On the ANOVA, position effect was set as first term, nitrogen as a second term and the interaction as third term, which one with its respective error. The block and its interactions were treated as random effects.

The normality of the residuals was verified by the Shapiro-Wilk test at $\alpha=0.01$ significance, and for secondary grain, only the systems comparison at $\alpha=$ 0.001 significance. The weight of primary grain from spikelets with one grain did not reached normality, and a square-root transformation was used to improve that outcome. Differences between the nitrogen levels means were determined using the Duncan method. To compare means from the AGR (control treatment) with positions inside the IS, the Dunnett two-sided method was used for treatment effects at $\alpha=0.10$ significance. 
For the significant effects of positions inside the IS, simple regression analyses for linear, quadratic and cubic polynomial degrees were determined. The mathematical models were chosen according to the equations with the best fit, confirmed by the higher determination coefficients and the significance of the regression $\mathrm{F}$ test, until $10 \%$ probability, or the lowest value of significance when the probability was above $10 \%$.

\section{RESULTS AND DISCUSSION}

The interaction between nitrogen and positions was significant for the oat above-ground biological yield, both on the systems comparison (five positions of IS and AGR) $(P=0.002)$ (Table 1$)$ or in IS (five positions) $(P=$ 0.013 ) (Figure 1a). After applying either $80 \mathrm{~kg} \mathrm{~N} \mathrm{ha}^{-1}$ or $12 \mathrm{~kg} \mathrm{~N} \mathrm{ha}^{-1}$, the biological yield of AGR was superior to all positions inside the IS (Table 1). Where $12 \mathrm{~kg} \mathrm{~N}^{-1}$ was applied within the IS, the oat biological yield tended to be nonlinear, with lower negative tree effects at central position of the oat track, which became more severe closer to the tree tracks $\left(\mathrm{R}^{2}=59.26, P=0.001\right)$. An 80 $\mathrm{kg} \mathrm{N} \mathrm{ha}^{-1}$ treatment in IS promoted the linear response in oat biological yield. Considering the slope between two adjacent tree tracks, the smallest elevation (position A) accumulated less phytomass than the highest elevation of the slope (position $\mathrm{E})\left(\mathrm{R}^{2}=68.31, P=0.007\right)$ (Figure 1a).

The oat phytomass accumulation tended to saturate at $50 \%$ daylight availability, and under severe shade (10\% of daylight availability), there was no fertilization effect on biomass production (SEMCHENKO; ZOBEL, 2005). It is possible that the light was not the only resource that interacted between the species, therefore it is also necessary to take account the water and nutrient dynamics inside the IS (QUINKENSTEIN et al., 2009; TSONKOVA et al., 2012).
The higher amplitude of biological yield did not occur in places where the higher nitrogen level was applied because the lodging mainly affected the reproductive phase in AGR and positions $B$ and $C$ inside IS (DEISS et al., 2014a). Under shade, oat increases the lignin and cellulose contents of stems, which compensates for the insufficient ontogenetic plasticity of stem biomass in response to the environment (light and nutrients) and provides mechanical support for plants grown under shade, enabling them to produce longer stems per unit of stem biomass (SEMCHENKO; ZOBEL, 2005). Under higher nitrogen levels, the higher interspecific interaction promotes growth regulation of oat for cereal production inside the IS.

During early oat development, the light quality modulates stem elongation and tillering, so the interrelationship between light availability and tiller development degree is determinant to the intraspecific competition and structure of the community (ALMEIDA; MUNDSTOCK, 2001). The tillering persistence determines the number of panicles at harvest (DEISS et al., 2014b).

The number of plants $\left(\mathrm{m}^{-2}\right)$ was not altered by nitrogen levels in the systems comparison $(P=0.52)$ neither by the positions in IS $(P=0.21)$. The panicle number $\left(\mathrm{m}^{-2}\right)$ was different for the average of nitrogen levels across the positions in the systems comparison $(P=0.0396)$, but not when considering only positions within the IS $(P=0.18)$. Compared to the AGR, the number of panicles was inferior at positions $\mathrm{A}, \mathrm{B}$ and $\mathrm{C}$ in IS $(P=0.04)$ (Table 2$)$. Within IS, no difference was observed for the panicle number between nitrogen levels and positions (Table 2). Wheat growing in a nine-year-old eucalyptus IS, established in a fan design and root pruned to a depth of $50 \mathrm{~cm}$ in northern India, had fewer earheads than wheat in a sole crop (KOHLI; SAINI, 2003).

Table 1 - Biological yield of oat (Avena sativa L. cv. IPR 126) under nitrogen levels (12.0 kg N ha ${ }^{-1}$ and $\left.80.0 \mathrm{~kg} \mathrm{~N}^{-1}\right)$ in positions of an agroforestry system (A_E) and traditional no-till agriculture (F) in subtropical Brazil

\begin{tabular}{cccccccc}
\hline & \multicolumn{7}{c}{ Positions } \\
\cline { 2 - 7 } N levels & $\mathrm{A}^{\mathrm{a}}$ & $\mathrm{B}$ & $\mathrm{C}$ & $\mathrm{D}$ & $\mathrm{E}$ & $\mathrm{F}$ & Mean \\
\cline { 2 - 7 } & \multicolumn{7}{c}{ Above-ground phytomass $\left(\mathrm{g} \mathrm{m}^{-2}\right)$} \\
\hline $80 \mathrm{~kg} \mathrm{~N} \mathrm{ha}^{-1}$ & $212 \mathrm{a}^{* * * \mathrm{~b}}$ & $223 \mathrm{a}^{* * *}$ & $291 \mathrm{a}^{* * *}$ & $324 \mathrm{a}^{* * *}$ & $387 \mathrm{a}^{* * *}$ & $610 \mathrm{a}$ Control & $341 \mathrm{~A}$ \\
$12 \mathrm{~kg} \mathrm{~N} \mathrm{ha}^{-1}$ & $136 \mathrm{~b}^{* * * *}$ & $186 \mathrm{a}^{* * *}$ & $279 \mathrm{a}^{* *}$ & $193 \mathrm{~b}^{* * *}$ & $184 \mathrm{~b}^{* * *}$ & $408 \mathrm{~b}$ Control & $231 \mathrm{~B}$ \\
Mean & $174^{* * *}$ & $204 * * *$ & $285^{* * *}$ & $258^{* * *}$ & $286^{* * *}$ & 509 Control & 286 \\
\hline
\end{tabular}

a positions: A: $2.8 \mathrm{~m}, \mathrm{~B}: 6.4 \mathrm{~m}, \mathrm{C}: 10.0 \mathrm{~m}, \mathrm{D}: 13.6 \mathrm{~m}$ and E: $17.2 \mathrm{~m}$ away from track positioned at the lowest elevation of the slope, between two adjacent eucalyptus (Eucalyptus dunnii Maiden) double line tracks [20 m (4 m x $3 \mathrm{~m})$ ]. Values followed (within column) by the same capital case letters and lowercase letters, are not significantly different using the Duncan's test at the 0.05 level of probability. ${ }^{\mathrm{b} *}{ }^{*}, * *, * * *$ and ${ }^{\mathrm{ns}}$ (within line) indicates the significance at $0.10,0.05,0.01$ and non significant, respectively, of the comparison with a control by the Dunnett two sided test 
Figure 1 - Oat (Avena sativa L. cv. IPR 126) above-ground biological yield (a) $\left(80.0 \mathrm{~kg} \mathrm{~N} \mathrm{ha}^{-1}: \mathrm{Y}=162.18+12.52 \mathrm{x}, \mathrm{R}^{2}=96.36\right.$, $\left.P=7.510^{-5} ; 12.0 \mathrm{~kg} \mathrm{~N} \mathrm{ha}^{-1}: \mathrm{Y}=45.73+35.52 \mathrm{x}-1.63 \mathrm{x}^{2}, \mathrm{R}^{2}=68.31, P=0.007\right)$, yield compounds spikelets per panicle $(\mathrm{b})(\mathrm{Y}=$ $\left.7.18+1.99 \mathrm{x}-0.83 \mathrm{x}^{2}, \mathrm{R}^{2}=85.46, P=0.052\right)$ and grains per spikelet $(\mathrm{c})\left(\mathrm{Y}=2.00-0.19 \mathrm{x}+0.020 \mathrm{x}^{2}-5.7610^{-4} \mathrm{x}^{3}, \mathrm{R}^{2}=99.72, P\right.$ $=0.04)$, yield (d) $\left(80.0 \mathrm{~kg} \mathrm{~N} \mathrm{ha}^{-1}: \mathrm{Y}=867.81-188.71 \mathrm{x}+21.10 \mathrm{x}^{2}-0.631 \mathrm{x}^{3}, \mathrm{R}^{2}=97.61, P=0.089 ; 12.0 \mathrm{~kg} \mathrm{~N}^{-1}: \mathrm{Y}=274.18\right.$ $\left.+38.71 \mathrm{x}-1.68 \mathrm{x}^{2}, \mathrm{R}^{2}=66.55, P=0.20\right)$ and harvest index $(\mathrm{e})\left(\mathrm{Y}=36.07-5.86 \mathrm{x}+0.556 \mathrm{x}^{2}-0.016 \mathrm{x}^{3}, \mathrm{R}^{2}=89.58, P=0.055\right)$ in agroforestry system, at A: $2.8 \mathrm{~m}, \mathrm{~B}: 6.4 \mathrm{~m}, \mathrm{C}: 10.0 \mathrm{~m}, \mathrm{D}: 13.6 \mathrm{~m}$ and E: $17.2 \mathrm{~m}$ away from track of eucalyptus (Eucalyptus dunnii Maiden) double line tracks under nitrogen levels (12.0 $\mathrm{kg} \mathrm{N} \mathrm{ha}^{-1}$ and $80.0 \mathrm{~kg} \mathrm{~N} \mathrm{ha}^{-1}$ fertilizer), in subtropical Brazil
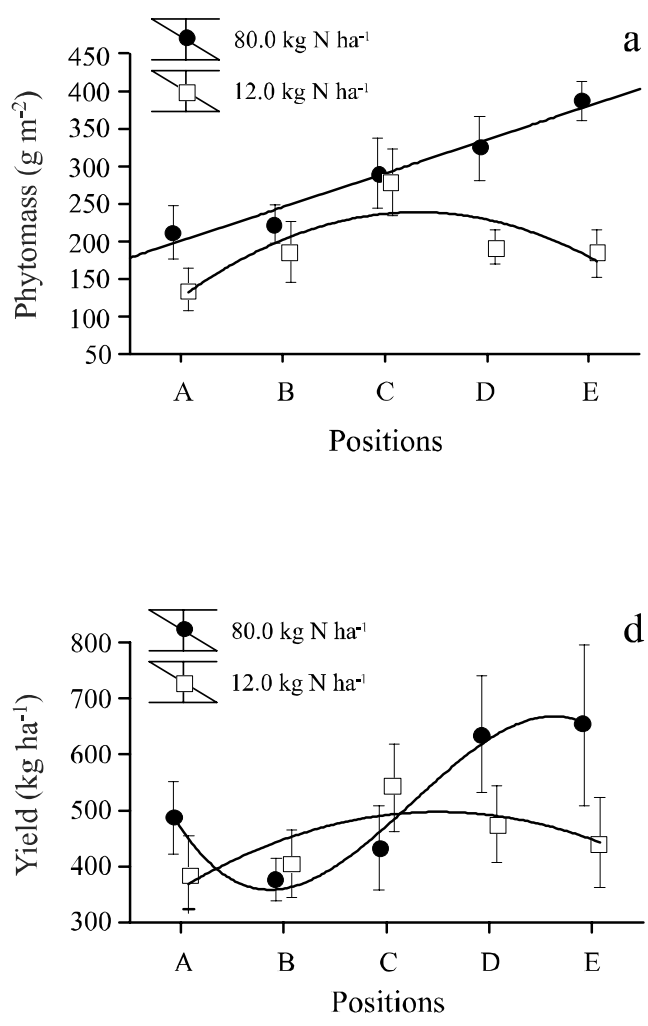

In oats, the tiller survival, stem elongation and initiation of spikelets and florets at the apical meristem will be all affected by competition (BROWNE; WHITE; BURKE, 2006). In the systems comparison, the number of spikelets per panicle was influenced by both nitrogen $(P=0.062)$ and position $(P=0.008)$ effects. Compared to AGR, the IS had fewer spikelets per panicle at positions A and $\mathrm{B}$. The number of spikelets per panicle where oat was submitted to $80 \mathrm{~kg} \mathrm{~N} \mathrm{ha}^{-1}$ was superior to $12 \mathrm{~kg} \mathrm{~N} \mathrm{ha}^{-1}$, although the higher nitrogen level increased the number of aborted spikelets per panicle $(P=0.007)$. Inside the IS, the higher nitrogen level increased both the number of spikelets $(P=0.027)\left(80 \mathrm{~kg} \mathrm{~N} \mathrm{ha}^{-1}: 17.8 \pm 1.3\right.$ and $12 \mathrm{~kg}$ $\left.\mathrm{N} \mathrm{ha}^{-1}: 15.6 \pm 1.4\right)$ and aborted spikelets per panicle $(P=$ $0.019)$ (Table 2). The number of spikelets per panicle was negatively affected by the trees presence $(P=0.0497)$ and the maximum was reached between positions $\mathrm{C}$ and $\mathrm{D}\left(\mathrm{R}^{2}=85.46, P=0.052\right)$ (Figure $\left.1 \mathrm{~b}\right)$.

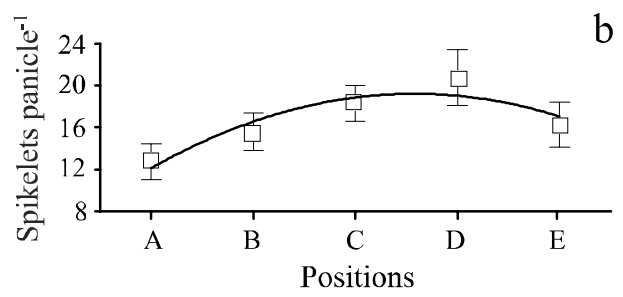

b
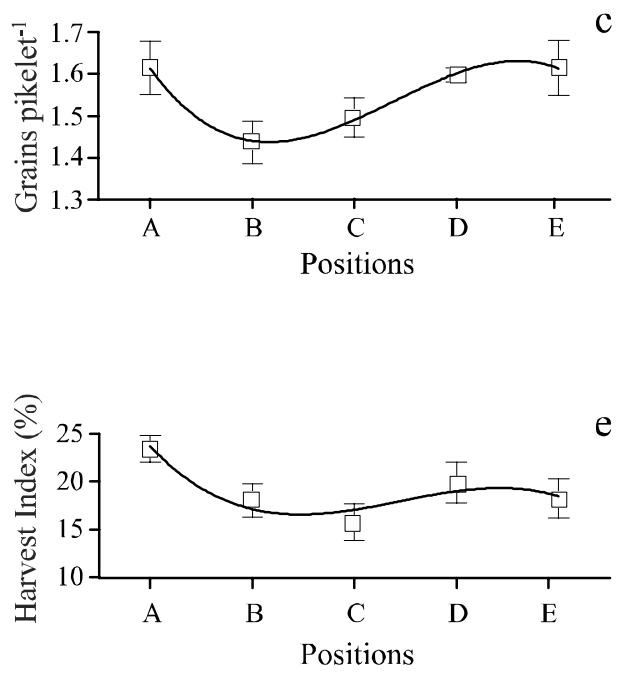

At the outset of oat fertilization followed by grain-filling, an imbalance of the photoassimilate supply and demand from competition between fully developed florets results in grain abortion (BROWNE; WHITE; BURKE, 2006). When higher nitrogen rates did not produce a great response in the panicle and spikelet numbers, the competition was less intense and fewer grains were aborted (BROWNE; WHITE; BURKE, 2006). The increased number of spikelets per panicle promoted by the higher nitrogen level and other recourses availability most likely resulted in the number of grains per spikelet reduction (Table 2).

The number of grains per spikelet was lower in the AGR compared to positions A, D and E in the IS $(P=0.004)$ (Table 2$)$. The higher number of grains per spikelet $(P=0.007)$ in both positions close to the trees (i.e., positions $\mathrm{A}$ and $\mathrm{E}$ ) and one intermediate position at the 
Table 2 - Yield compounds of oat (Avena sativa L. cv. IPR 126) under nitrogen levels in positions of an agroforestry system (A_E) and traditional no-till agriculture $(\mathrm{F})$ in subtropical Brazil

\begin{tabular}{|c|c|c|c|c|c|c|c|}
\hline \multirow{2}{*}{$\mathrm{N}$ levels } & \multicolumn{6}{|c|}{ Positions } & \multirow{2}{*}{ Mean } \\
\hline & $\mathrm{A}^{\mathrm{a}}$ & $\mathrm{B}$ & $\mathrm{C}$ & $\mathrm{D}$ & $\mathrm{E}$ & $\mathrm{F}$ & \\
\hline \multicolumn{8}{|c|}{ Panicle $\left(\mathrm{m}^{-2}\right)$} \\
\hline $80 \mathrm{~kg} \mathrm{~N} \mathrm{ha}^{-1}$ & 219 & 186 & 163 & 211 & 258 & 278 & 219 \\
\hline $12 \mathrm{~kg} \mathrm{~N} \mathrm{ha}^{-1}$ & 182 & 179 & 199 & 232 & 233 & 235 & 210 \\
\hline Mean & $201 * \mathrm{~b}$ & $183 * *$ & $181 * *$ & $222^{\mathrm{ns}}$ & $246^{\mathrm{ns}}$ & 256 Control & 215 \\
\hline \multicolumn{8}{|c|}{ Spikelets $\left(\right.$ panicle $\left.^{-1}\right)$} \\
\hline $80 \mathrm{~kg} \mathrm{~N} \mathrm{ha}^{-1}$ & 14.9 & 14.9 & 18.4 & 23.5 & 17.2 & 25.2 & $19 \mathrm{~A}$ \\
\hline $12 \mathrm{~kg} \mathrm{~N} \mathrm{ha}^{-1}$ & 10.5 & 16.3 & 18.1 & 18 & 15.3 & 19 & $16.2 \mathrm{~B}$ \\
\hline Mean & $12.7 * *$ & $15.6^{*}$ & $18.3^{\mathrm{ns}}$ & $20.8^{\mathrm{ns}}$ & $16.3^{\mathrm{ns}}$ & 22.1 Control & 17.6 \\
\hline \multicolumn{8}{|c|}{ Aborted spikelets $\left(\right.$ panicle $\left.^{-1}\right)$} \\
\hline $80 \mathrm{~kg} \mathrm{~N} \mathrm{ha}^{-1}$ & 2.45 & 2.64 & 3.27 & 2.75 & 2.4 & 2.96 & $2.75 \mathrm{~A}$ \\
\hline $12 \mathrm{~kg} \mathrm{~N} \mathrm{ha}^{-1}$ & 0.5 & 1.21 & 1.28 & 0.43 & 1.02 & 0.82 & $0.88 \mathrm{~B}$ \\
\hline Mean & 1.48 & 1.93 & 2.27 & 1.59 & 1.71 & 1.89 & 1.81 \\
\hline \multicolumn{8}{|c|}{ Grain $\left(\right.$ spikelet $\left.^{-1}\right)$} \\
\hline $80 \mathrm{~kg} \mathrm{~N} \mathrm{ha}^{-1}$ & 1.46 & 1.34 & 1.48 & 1.6 & 1.51 & 1.4 & $1.47 \mathrm{~B}$ \\
\hline $12 \mathrm{~kg} \mathrm{~N} \mathrm{ha}^{-1}$ & 1.77 & 1.53 & 1.51 & 1.6 & 1.72 & 1.43 & $1.59 \mathrm{~A}$ \\
\hline Mean & $1.61 * *$ & $1.44^{\mathrm{ns}}$ & $1.5^{\mathrm{ns}}$ & $1.6^{*}$ & $1.61 * *$ & 1.41 Control & 1.53 \\
\hline \multicolumn{8}{|c|}{ W. $1001^{o}(g)^{c}$} \\
\hline $80 \mathrm{~kg} \mathrm{~N} \mathrm{ha}^{-1}$ & 3.1 & 2.7 & 2.7 & 2.4 & 2.6 & 2.6 & 2.7 \\
\hline $12 \mathrm{~kg} \mathrm{~N} \mathrm{ha}^{-1}$ & 3.1 & 3.1 & 2.7 & 2.7 & 2.9 & 2.7 & 2.9 \\
\hline Mean & 3.1 & 2.9 & 2.7 & 2.6 & 2.8 & 2.6 & 2.8 \\
\hline \multicolumn{8}{|c|}{ W. $1002^{\circ}(g)^{d}$} \\
\hline $80 \mathrm{~kg} \mathrm{~N} \mathrm{ha}^{-1}$ & 1.3 & 1.1 & 1.1 & 1.1 & 1 & 1.2 & 1.1 \\
\hline $12 \mathrm{~kg} \mathrm{~N} \mathrm{ha}^{-1}$ & 1.3 & 1.3 & 1.1 & 1.1 & 1.2 & 1.2 & 1.2 \\
\hline Mean & 1.3 & 1.2 & 1.1 & 1.1 & 1.1 & 1.2 & 1.2 \\
\hline \multicolumn{8}{|c|}{ W. 100 sole $1^{\mathrm{o}}(\mathrm{g})^{\mathrm{e}}$} \\
\hline $80 \mathrm{~kg} \mathrm{~N} \mathrm{ha}^{-1}$ & 1.4 & 1.1 & 1 & 1 & 1.1 & 1.1 & 1.1 \\
\hline $12 \mathrm{~kg} \mathrm{~N} \mathrm{ha}^{-1}$ & 1.5 & 1.1 & 0.9 & 0.9 & 0.9 & 0.8 & 1 \\
\hline Mean & $1.5^{* *}$ & $1.1^{\mathrm{ns}}$ & $0.9^{\text {ns }}$ & $1^{\mathrm{ns}}$ & $1^{\mathrm{ns}}$ & 0.9 Control & 1.1 \\
\hline
\end{tabular}

a positions: A: $2.8 \mathrm{~m}, \mathrm{~B}: 6.4 \mathrm{~m}, \mathrm{C}: 10.0 \mathrm{~m}, \mathrm{D}: 13.6 \mathrm{~m}$ and E: $17.2 \mathrm{~m}$ away from track positioned at the lowest elevation of the slope, between two adjacent eucalyptus (Eucalyptus dunnii Maiden) double line tracks [20 m (4 m x $3 \mathrm{~m})] .{ }^{\mathrm{b}} *, * *, * * *$ and ${ }^{\mathrm{ns}}$ (within column) indicates the significance at $0.10,0.05$, 0.01 and non significant, respectively, of the comparison with a control by the Dunnett two sided test. Weight of ${ }^{c}$ primary and ${ }^{\mathrm{d}}$ secondary grains with husks, from spikelets with two or ${ }^{\mathrm{e}}$ one grains. Values followed by the same capital case letters (within column) are not significantly different using the Duncan's test

smallest elevation of the slope between two adjacent tree tracks (i.e., position D) partially compensated for the lower number of spikelets per panicle within IS and compared to AGR (Table 2). Within the arborized system, the number of grains per spikelets at central and one intermediate position (i.e., positions B and C) was lower than it was nearer to the trees and the other intermediate position (i.e., positions A, $\mathrm{D}$ and E) $\left(R^{2}=99.72, P=0.04\right)$ (Figure 1c).
After anthesis, the "competition will be confined to grains that are being filled" (BROWNE; WHITE; BURKE, 2006). The 100 grain weight of the primary grains with husks, including separately spikelets with one or two grains, and the secondary grains were not different between the nitrogen levels in the systems comparison and inside the IS. For the average of nitrogen levels, only the position $\mathrm{A}$ inside the IS had a higher weight for the 
primary grains of spikelets with one grain than the AGR (Table 2). There were no tertiary grains observed in the spikelets studied. As the nitrogen rate decreased from 80 to $12 \mathrm{~kg} \mathrm{~N} \mathrm{ha}^{-1}$, and the distance from the arboreal component decreased inside the IS, the proportion of secondary grain relative to primary grain increased more in numbers than in weight (Table 2 and Figure 1c).

In the systems comparison, the oat yield interacted with nitrogen levels and positions $(P=0.069)$. AGR with $80 \mathrm{~kg} \mathrm{~N} \mathrm{ha}^{-1}$ had higher yield than positions A, B and $\mathrm{C}$ in the IS, however, did not differ from positions $\mathrm{D}$ and $\mathrm{E}$. The AGR with $12 \mathrm{~kg} \mathrm{~N} \mathrm{ka}^{-1}$ did not differ from the IS. Inside of each position, the $80 \mathrm{~kg} \mathrm{~N} \mathrm{ha}^{-1}$ treatment increased the yield of oats only on position $\mathrm{E}$ inside IS and in the AGR. In the area designated for the annual crops in the IS, the oat yield was also a result of the interaction between the nitrogen level and positions between the tree tracks $(P=0.109)$ (Table 3). When 12 $\mathrm{kg} \mathrm{N} \mathrm{ha}{ }^{-1}$ was applied, the yield tended to be non-linear, increasing as the distance from the trees increased, reaching a peak yield between positions $\mathrm{C}$ and $\mathrm{D}\left(\mathrm{R}^{2}\right.$ $=66.55, P=0.20$ ) (Fig. $1 \mathrm{~d}$ ). The cubic response was observed where $80 \mathrm{~kg} \mathrm{~N} \mathrm{ha}^{-1}$ was applied, which gave a strong yield reduction between positions $A$ and $D\left(R^{2}=\right.$ 97.61 $P=0.089$ ) (Figure 1d).

This evidence is that an adjustment in the nitrogen levels of the IS should be taken into account, with attention to the complex interspecific interaction between annuals and perennial crops. In the central position between eucalyptus tracks, the higher nitrogen level did not increase both the biological and grain yields, suggesting that the nitrogen level for these places should be inferior of $80 \mathrm{~kg} \mathrm{~N} \mathrm{ha}^{-1}$. The higher nitrogen level increased the grain yield at position $\mathrm{E}$ inside the IS, indicating that the nitrogen level should be maintained or even increased.

In Spanish meadows, the close vicinity of holmoak trees (Quercus ilex L.) reduced the oat cereals yield, which was manly attributed to the competition for light and water (MORENO; OBRADOR; GARCÍA, 2007). The same authors found that trees reduced plant density, but plants height and weight as well as the number and weight of grains per plant did not vary with the distance from the trees (MORENO; OBRADOR; GARCÍA, 2007). In this study, the number of plants was not altered by nitrogen levels in the systems comparison neither by the positions in IS. However, its important emphasize that, the reduction in productivity would have been more pronounced if the harvest had been made mechanically, where was detected the lodging interference, because lodged plants would not be harvested (ESPINDULA et al., 2010).

Inside IS, the cubic response of grain yield was observed where $80 \mathrm{~kg} \mathrm{~N} \mathrm{ha}^{-1}$ was applied (Fig. 1d), which may have occurred as a consequence of yield reductions, most likely aggravated by lodging in positions B and C (DEISS et al., 2014a). In contrast, the rainwater interception and redistribution (GHAZAVI et al., 2008, SILES et al., 2010) by the eucalyptus could have added to the alleviation of below-ground competition promoted by nitrogen fertilization, which favored the grain yield at the highest slope elevation (i.e., positions

Table 3 - Yield and harvest index of oat (Avena sativa L. cv. IPR 126) under nitrogen levels (N) in positions of an agroforestry system (A_E) and traditional no-till agriculture (F) in subtropical Brazil

\begin{tabular}{|c|c|c|c|c|c|c|c|}
\hline \multirow{2}{*}{$\mathrm{N}$ levels } & \multicolumn{6}{|c|}{ Positions } & \multirow{2}{*}{ Mean } \\
\hline & $\mathrm{A}^{\mathrm{a}}$ & B & $\mathrm{C}$ & $\mathrm{D}$ & $\mathrm{E}$ & $\mathrm{F}$ & \\
\hline \multicolumn{8}{|c|}{ Yield $\left(\mathrm{kg} \mathrm{ha}^{-1}\right)^{\mathrm{d}}$} \\
\hline $80 \mathrm{~kg} \mathrm{~N} \mathrm{ha}^{-1}$ & $487 \mathrm{a}^{* \mathrm{~b}}$ & $377 \mathrm{a}^{* * *}$ & $433 \mathrm{a}^{* *}$ & $636 a^{\mathrm{ns}}$ & $652 a^{\mathrm{ns}}$ & 744 a Control & $555 \mathrm{~A}$ \\
\hline $12 \mathrm{~kg} \mathrm{~N} \mathrm{ha}^{-1}$ & $386 \mathrm{a}^{\mathrm{ns}}$ & $405 \mathrm{a}^{\mathrm{ns}}$ & $541 \mathrm{a}^{\mathrm{ns}}$ & $476 \mathrm{a}^{\mathrm{ns}}$ & $443 b^{\mathrm{ns}}$ & 496 b Control & $458 \mathrm{~B}$ \\
\hline Mean & $436 * * \mathrm{~b}$ & $391 * * *$ & $487^{\mathrm{ns}}$ & $556^{\mathrm{ns}}$ & $547^{\mathrm{ns}}$ & 620 Control & 506 \\
\hline \multicolumn{8}{|c|}{ Harvest index $(\%)^{\mathrm{e}}$} \\
\hline $80 \mathrm{~kg} \mathrm{~N} \mathrm{ha}^{-1}$ & 21.1 & 15.6 & 13.4 & 17.3 & 14.9 & 10.7 & $15.5 \mathrm{~B}$ \\
\hline $12 \mathrm{~kg} \mathrm{~N} \mathrm{ha}^{-1}$ & 25.8 & 20.5 & 18.1 & 22.5 & 21.6 & 10.8 & $19.9 \mathrm{~A}$ \\
\hline Mean & $23.4 * * *$ & $18.0 * * *$ & $15.8 * *$ & $19.9 * * *$ & $18.2 * * *$ & 10.7 Control & 17.7 \\
\hline
\end{tabular}

a positions (P): A: $2.8 \mathrm{~m}, \mathrm{~B}: 6.4 \mathrm{~m}, \mathrm{C}: 10.0 \mathrm{~m}, \mathrm{D}: 13.6 \mathrm{~m}$ and E: $17.2 \mathrm{~m}$ away from track positioned at the lowest elevation of the slope, between two adjacent eucalyptus (Eucalyptus dunnii Maiden) double line tracks [20 m (4 m x $3 \mathrm{~m}$ )]. Values followed by the same capital case letters (within column) and lowercase letters (within column inside each position) are not significantly different using the Duncan's test. ${ }^{\mathrm{b}} *, * *, * * *$ and ${ }^{\mathrm{ns}}$ (within column) indicates the significance at $0.10,0.05,0.01$ and non significant, respectively, of the comparison with a control by the Dunnett two sided test. ${ }^{\mathrm{c}}$ Estimated with $13 \%$ moisture. ${ }^{\mathrm{d}}$ Calculated without moisture of grains 
$\mathrm{D}$ and $\mathrm{E}$ ) between two adjacent tree tracks (Figure 1d). Because the trees were planted at a guideline level, the rainwater runoff intercepted by trees always favors the highest elevation of the slope between the tree tracks. Furthermore, Thevathasan and Gordon (1997) measured the increased nitrification rates near $(<2.5 \mathrm{~m})$ the poplar row (Populus spp. clone DN 177) in a 7 to 9 year old poplar-barley intercropping, which was disc-plowed cultivated in the first 4 years in Ontario, Canada, which they attributed to the poplar leaf distribution close to the tree row, which in turn increased the above-ground biomass and nitrogen grain concentration of barley.

The harvest index was negatively affected by increases in the nitrogen level, both in the systems comparison $(P=0.004)$ and inside the IS $(P=0.015)$. In AGR, lower value was observed for the harvest index than all positions in the IS, except for position $\mathrm{C}$, which from it did not differ $(P=0.001)$ (Table 3$)$. Inside IS $(P=0.056)$, the harvest index had a cubic response for the position effect, decreasing from position $\mathrm{A}$ until the middle between positions $\mathrm{B}$ and $\mathrm{C}$, increasing until the middle between position $\mathrm{D}$ and $\mathrm{E}$, and again decreasing slightly until the end of the oat track at the highest elevation of the slope $\left(\mathrm{R}^{2}=89.58, P=0.055\right)$ (Figure 1e). The harvest index of wheat under a poplar plantation decreased with increasing the trees age, from 4 to 6 years old (GILL; SINGH; KAUR, 2009). The wheat intercropped with eucalyptus had a similar harvest index but lower above-ground biological yield than wheat as a sole crop (KOHLI; SAINI, 2003).

The lower heat load during wheat grain filling promoted by eucalyptus in IS, combined with subsequent increased grain filling duration, can mitigate the effect of quantitative and qualitative reductions in radiant energy during the wheat growth initial stages (KOHLI; SAINI, 2003). The oat aboveground biological yield was higher where $80 \mathrm{~kg} \mathrm{~N} \mathrm{ha}^{-1}$ was applied both on IS and AGR (Table 1 and Fig. 1a). However, at the same locations where the growth was better (Table 1 and Fig. 1a), the harvest indexes were poorer, with exception of positions E next to the trees, which had a subtle decrease (Table 3 and Fig. 1e). The nitrogen increased the biological yield and decreased the harvest index to a greater extent by antagonistic effect, where interspecific interaction between oats and eucalyptus was low, mainly on the lowest elevations between two adjacent tree tracks (Table 3 ).

Further studies combining nitrogen levels with other agronomic practices, e.g., cultivars, plant growth regulators and plant arrangements, are necessary to sustainably increase the yield potential of small cereals in the IS of subtropical regions.

\section{CONCLUSION}

Oats have the capacity to cohabitate with four years old eucalyptus, and nitrogen levels increase the oat yield differently at distances from the trees inside the IS. Therefore different nitrogen levels should be used at those distances to increase nitrogen use efficiency inside IS in subtropical Brazil and promote sustainability on agroecosystems.

\section{REFERENCES}

ALMEIDA, M. L.; MUNDSTOCK, C. M. Oat tillering affected by light quality, in plants under competition. Ciência Rural, v. 31, p. 393-400, 2001.

BROWNE, R. A.; WHITE, E. M.; BURKE, J. I. Effect of nitrogen, seed rate and plant growth regulator (chlormequat chloride) on the grain quality of oats (Avena sativa). Journal of Agricultural Science, v. 141, p. 249-258, 2003.

BROWNE, R. A.; WHITE, E. M.; BURKE, J. I. Responses of developmental yield formation processes in oats to variety, nitrogen, seed rate and plant growth regulator and their relationship to quality. Journal of Agricultural Science, v. 144, p. 533-545, 2006.

CAVIGlione, J. H. et al. Cartas climáticas do Paraná. Londrina: IAPAR, 2000. 1 CD-ROM. Disponível em: <http:// www. iapar.br/modules/conteudo/conteudo.php?conteudo=677> Acesso em: 06 jul. 2015.

DEISS, L. et al. Oat growth under different nitrogen doses in eucalyptus alley cropping system in subtropical Brazil. Revista Ciência Agronômica, v. 45, p. 1014-1023, 2014a.

DEISS, L. et al. Oat tillering and tiller traits under different nitrogen levels in an eucalyptus agroforestry system in Subtropical Brazil. Ciência Rural, v. 44, p. 71-78, 2014b.

ESPINDULA, M. C. et al. Nitrogen application methods and doses in the development and yield of wheat. Ciência e Agrotecnologia, v. 34, p. 1404-1411, 2010.

GHAZAVI, G. et al. Hedgerow impacts on soil water transfer due to rainfall interception and root-water uptake. Hydrological Processes, v. 22, p. 4723-4735, 2008.

GILL, R. I. S.; SINGH, B.; KAUR, N. Productivity and nutrient uptake of newly released wheat varieties at different sowing times under poplar plantation in north-western India. Agroforestry Systems, v. 76, p. 579-590, 2009.

KOHLI, A.; SAINI, B. C. Microclimate modification and response of wheat planted under trees in a fan design in northern India. Agroforestry Systems, v. 58, p. 109-118, 2003.

MORENO, G.; OBRADOR, J. J.; GARCÍA, A. Impact of evergreen oaks on soil fertility and crop production in intercropped dehesas. Agriculture, Ecosystems and Environment, v. 119, p. 270-280, 2007. 
PORFÍRIO-DA-SILVA, V. et al. Arborização de pastagens com espécies florestais madeireiras: implantação e manejo. Colombo, PR: Embrapa Florestas, 2009. 47 p.

PRASAD, J. V. N. S. et al. Tree row spacing affected agronomic and economic performance of Eucalyptus-based agroforestry in Andhra Pradesh, Southern India. Agroforestry Systems, v. 78, p. 253-267, 2010.

QUINKENSTEIN, A. et al. Ecological benefits of the alley cropping agroforestry system in sensitive regions of Europe. Environmental Science \& Policy, v.12, p. 1112-1121, 2009.

SANTOS, H. G. et al. Sistema Brasileiro de Classificação de Solos. 2. ed. Rio de Janeiro: Embrapa Solos, 2006.

SEMCHENKO, M.; ZOBEL, K. The effect of breeding on allometry and phenotypic plasticity in four varieties of oat (Avena sativa L.). Field Crops Research, v. 93, p. 151-168, 2005.
SILES, P. et al. Rainfall partitioning into through fall, stem flow and interception loss in a coffee (Coffea arabica L.) monoculture compared to an agroforestry system with Inga densiflora. Journal of Hydrology, v. 395, p. 39-48, 2010.

TheVATHASAN, N. V.; GORDON, A. M. Poplar leaf biomass distribution and nitrogen dynamics in a poplarbarley intercropped system in southern Ontario, Canada. Agroforestry Systems, v. 37, p. 79-90, 1997.

TSONKOVA, P. et al. Ecological benefits provided by alley cropping systems for production of woody biomass in the temperate region: a review. Agroforestry Systems, v. 85, p. 133-152, 2012.

WhiTE, E. M.; MCGAREL, A. S. L.; RUDDLE, O. The influence of variety, year, disease control and plant growth regulator application on crop damage, yield and quality of winter oats (Avena sativa). Journal of Agricultural Science, v. 140, p. 31-42, 2003. 